\title{
Problems of Development of the Uzbek Language in Current Society
}

\author{
Sh. I. Shozamonov', S. A. Nazarova1, B. B. Djuraev² \\ ${ }^{1}$ Chinese Philology Department, Tashkent State University of Oriental Studies, Tashkent, Uzbekistan \\ ${ }^{2}$ Educational Center under Academy of Sciences of Uzbekistan, Tashkent, Uzbekistan \\ Email: bbdjuraev@yandex.ru
}

How to cite this paper: Shozamonov, Sh. I., Nazarova, S. A., \& Djuraev, B. B. (2021). Problems of Development of the Uzbek Language in Current Society. Open Journal of Modern Linguistics, 11, 613-620.

https://doi.org/10.4236/ojml.2021.114046

Received: October 18, 2020

Accepted: August 7, 2021

Published: August 10, 2021

Copyright $\odot 2021$ by author(s) and Scientific Research Publishing Inc. This work is licensed under the Creative Commons Attribution International License (CC BY 4.0).

http://creativecommons.org/licenses/by/4.0/

\begin{abstract}
The article analyzes the status and history of the Uzbek language in Central Asia, the relationship with foreign languages, the state policy in the development of the Uzbek language, the impact of Russian phrases on Uzbek speech. The article is the result of practical observations of the Uzbek language in public life. The article is important in terms of studying the phrases learned from the Russian language in the Uzbek spoken language. Issues related to it are among the most studied articles in Uzbek sociolinguistics. In this regard, some of the points raised in the article may be controversial. Methods: analysis-synthesis, diachronic and synchronous, comparative and extra linguistic analysis determine the method of the article. Uzbek language is associated with the development in recent years, the study of problems and their solutions of the article identified as goals and tasks.
\end{abstract}

\section{Keywords}

Language, Society, Alphabet, Alphabetic Writing, According to Cyrillic, Latin, Turkish, Conversation, Vocabulary Units, Orally, in Written Language, Decrees, Decisions, Borrowed Lexemes and Arabic, Farsi, Russian, English, Chinese, Japanese and Korean Languages

\section{Introduction}

Forty million people around the world speak Uzbek. Due to its geographical distribution, the language is widely spoken in Afghanistan, Kazakhstan, Kyrgyzstan, Turkmenistan, Tajikistan and the Xinjiang Autonomous Region of the People's Republic of China (Ulko, 2019). Today, Uzbek language along with other Turkic languages is studied in the United States, Russia, Sweden and in China. According to David Brokaw, assistant director of the Melikan Center, "Uzbek is one of 
the least taught languages" (David Brokaw, 2015).

The phrases analyzed in the article are both practical and theoretical in understanding the differences between Uzbek oral and written speech. After the transition of the Uzbek language to the Latin alphabet, the pronunciation changes in speech. The transition from the Cyrillic alphabet to the Latin alphabet is complicated by people. Hamida Shaymardonova, a biology and elementary school teacher at Sherabad District School No. 42, asked, "How do you understand that instead of Latin letters, Cyrillic letters with billboards are still hung on the roofs, or that restaurants or companies are called by Russian, Turkish, or English names?" shows that the attitude towards the Uzbek language is the same not only in the center, but also in the countryside.

Today, the world is going through a period of globalization, and many languages are trying to adapt to it and survive. The Uzbek language is no exception. At present, the diaspora of Uzbek-speaking peoples around the world is growing. Such tendencies, which are not typical of the Uzbek people, are bound to follow. It is clear that this will lead to the alienation of a certain ethnic group of the Uzbek people from their native language.

In today's world, English, Chinese and Russian are the official languages of the United Nations. Taking into account these criteria, Uzbekistan pays special attention to the study of foreign and oriental languages. In 2002, Westminster University in England and the University of Singapore in Malaysia were established. The language of instruction and studying there is English. The Uzbek-Chinese Confucius Institute, a non-governmental organization has been operating in Uzbekistan since 2004. The resolution of the first President of the Republic of Uzbekistan dated December 10, 2012 No PP-1875 "On measures to further improve the system of learning foreign languages." In September 2014, by the decision of the President No. 2228, the "Faculty of Chinese Studies" was established at the Tashkent State Institute of Oriental Studies.

Also, in accordance with the decision of the President No. 4680 of April 26, 2020, the Tashkent State Institute of Oriental Studies was transformed into the university. Three South Korean Universities such as Puchon, Inha, and Yodju were opened in Tashkent. Webster University of the United States operates its branch in Tashkent.

At schools of Uzbekistan, the study of local languages is Tajik, Kazakh, Kyrgyz, Turkmen.

It is gratifying that in the Central Asian region, especially in Uzbekistan, the systematic study of the Tajik language is being introduced. There are good opportunities to study the Pamir languages (there are six languages in the region) through the Tajik language, to study the historical similarity of the Pamir and Turkic languages (Aftondil Erkinov, 2015: pp. 150-151).

Academician Naim Karimov says: "Until now, we have studied only Russian, in addition to Uzbek. Today's youth and tomorrow's youth are required not only to learn English, German, French, Japanese and Korean, but also to write articles, 
pamphlets and books in these languages" (Naim Karimov, 2020).

Today's tradition of development suggests that in addition to knowing the language, one must have a profession. This was stated by the First President of the Republic of Uzbekistan I. A. Karimov says in a very beautiful way: "It is not enough to know English or the theory of market economy, you need to know life. Our youth must enter life, because who will bear the burden of Uzbekistan if our youth does not?".

Recently, it has become customary to provide advertising texts in English. In this sense, it is impossible not to agree with Doctor of philological sciences A.B. Djuraev's views on the problems facing the Uzbek text today: "In the textual environment of Uzbekistan, a strong, new rival has emerged in front of the Uzbek text, the name of this opponent is the English text" (A. B. Djuraev, 2016: pp 7-11). In the near future, Uzbek may face English as well as Chinese.

The collapse of the former Soviet Union and today's external and internal factors have led to acute problems with language policy in Central Asia. Taking into account these aspects of the issue, the study and classification of words and phrases learned from other languages in the lexical layers of the Uzbek language, which is the largest language among today's Turkic languages, awaits its solution. In this regard, it is of practical importance to analyze certain aspects of past and present trends in today's Uzbek-Russian relations.

\section{Popularization of the Russian Language in Uzbekistan and Its Historical and Ideological Foundations}

It has been more than a hundred years since the Uzbek language and the Russian language coexisted in our country. After the formation of the USSR, Russian became the dominant language in the Soviet space as an international language. In recent times, the situation has become such that even speakers of sister languages belonging to the same language family, who understand each other, have been able to exchange ideas, ideas through Russian. Turkic languages in Central Asia are a clear example of this. During the Soviet era, Russian became the only language of communication in the former Soviet Union. In addition, the Russian language still defines the socio-ideological thinking of the nations, peoples and peoples living in the former Soviet Union. Until recently, Russian University of Economics named after Plekhanov, Moscow State University named after Lomonosov, Russian State University of Oil and Gas named after Gubkin and the Moscow State Institute of International Relations have branches, the number of branches of Russian universities has increased from five to nine.

It is no secret that after the collapse of the former Soviet Union, the Russian language also faced difficult situations. For example, in the Baltic Republics and Ukraine, a language policy was pursued to restrict the Russian language, which was deeply ingrained in the national feelings of the people. On the contrary, in Central Asia, which was part of the former Soviet Union, the situation was peculiar. 1) About $60 \%$ of the population of Kazakhstan are Russians. The northern 
regions were also completely Russified, and the Russian way of life was deeply ingrained in their cultural life. 2) The dependence of Kyrgyzstan and Tajikistan on Russia in terms of population, economic instability, security and defense, which increases the need for the Russian language. 3) Russia pursues a language policy in Central Asia, taking into account its interests. Having correctly assessed the above factors, today's Russian state has developed measures to protect the Russian language in the former Soviet Union. The Constitution of the Russian Federation includes a clause on the protection of the Russian language.

Attitudes towards the Russian language in Uzbekistan have not changed today, as they did in the former Soviet Union. From the center, the tendency to learn Russian in regional, district, city, and even remote rural schools of the country remains strong. So what traditions remain its main factor? A reasonable question arises. In our view, the following remain its main factors: 1) whether it is a city or a village, whether the parents of today's youth in their time served in the Soviet Army or studied in Russian universities; 2) during the years of independence, most parents went to work in Russia for a living; 3 ) the fact that the majority of Uzbek youth still form positive opinions about Russia through adults; 4) ease of access to Russia; 5) limited assimilation of world scientific and technical achievements through the Uzbek language; 6) The belief that Russia is a great country and especially the desire of parents to educate their children in Russian schools; 7) the fact that feature films of various genres are broadcast on cable television, etc., define its essence.

It is no secret that for the past decades, the Uzbek language has been under pressure from the Russian language. Therefore, in the oral speech of most people, many appropriate and inappropriate phrases from the Russian language were adopted. This has had a negative impact on the attractiveness of the Uzbek language and is expected to be analyzed as a new phenomenon of Uzbek oral speech. In this regard, the following attempts are made to reveal the semantic features of the Uzbek equivalents of a number of words and phrases borrowed from the Russian language.

\section{Semantic Features of Words Borrowed from Russian into Uzbek Language}

Over the past decades, thousands of phrases from the Russian language have been mastered in the Uzbek language in our region. The following is a semantic analysis of Russian words: “ $\boldsymbol{H}^{\prime 1}$ "in Uzbek”, “ва", “карочи” or “карочида", "қисқаси", "да" in Russian speech on the phone, "ха" "yes" in Uzbek, in conversation how to understand, "in Russian" как это можно понят "буквално-тахминан-roughly”, чистый-(чистий) pure, полний full (in the sense of full, complete, whole), приятно (used in such senses as pleasant, delicious.) the phrase is more often used in the form of the phrase somehow nice.

Просто (simply in the sense of literally), паспортний стол passport desk,

${ }^{1}$ We found it appropriate to give the words and phrases in Russian in italics so that they are clear to the students. 
table, стол находка, списка (in the sense of a note, list), кчёрту (in the sense of a demon), уже (in the sense of already), давним-давно (in the sense of before, long ago), рискованний (in the sense of risk), насморк (in the sense of runny nose), насмерт (in the sense of dead on the ground). Стиляга Hipster "У" шунақанги стиляга кўявер-(It is used in expressions such as he is hipster let him in that style). Today, the phrase "style" is preserved in the oral speech of the residents of Zarabog, Shalkan mountain and foothills of Sherabad district of Surkhandarya region. Also, the word "я" in the speech of the people of this region is widely used in the sense of "surprise". The Russian word "я" теans "мен" ( $\mathrm{am}$ ) in Uzbek.

Беспредел-When he was young, he had such а беспредел (in the sense that it is used to describe the interlocutor's behavior in relation to someone's life, negatively or positively), which is still used in the sense that it is no longer calm down . Or he was at the time вобшим беспредел-fully mass. You see, he's still smart. That's right, that's fine. Is this still his man?

The words "Брон", "билет" - "booking" and "ticket" are also used in conjunction with the expressions "order" and "ticket". The word "весь", which means weight and things, is also widely used in Uzbek speech. The word is widely used in the sense of "веси оғир", "юки оғир"- "heavy", "heavy burden". In the word "Веси оғир"- "heavy", "вес" is used as a semi-shield.

Трудовая книжка-(workbook) This term is also widely used in the Uzbek language. As I was walking down the hallway out of my house on January 11, 2017, I overheard a conversation between two people who had condemned 56 -year-olds in front of our store next door. The content of the conversation was as follows: three years left, is it hard work...? that is, it is clear from the interlocutor's statement that, in the first place, he has no permanent place of work. Secondly, the content of the conversation shows that the man is from Tashkent. Third, it is known from his speech that he read during the Soviet regime.

This is because the word "Трудовая книжка" is widely used today in the speech of those who were brought up in the Soviet era.

Тупой (low mind person) is an assimilated word. Uzbek is one of the most deeply ingrained expressions in oral speech.

Замкунтый (a human who is not interfering with people) is an assessment of the acquired or innate character of a certain person in life.

As we listened to the speeches of the bus with route N37 drivers traveling in the direction from Tashkent city to Kuyluk market, the following phrases were actively used in their speeches. "Данний время, интерваль, гонять, бир секунд, бир минут, пошёлсан: Данний время қайрдасан, where are now? интервал, interval, one second, one minute: where is the interval, you have to follow, don't yоu гонять (гнат) follow him? I'll catch up with you in a second, not even a minute since He left." From this conversation, it is clear that the bus driver was dissatisfied with the other side. On the other hand, the level of attitude to the Uzbek language is very low, the language and culture of communication are not 
formed.

Today, the phrase "есть" is widely used among leaders. "We remember that."

“Бизлар буни есть (Russian word) қиламиз”. We will do it. "Хамма ишларни битириб под ключ (Russian expression) беришади”. They finish all the work and give the key for the house.

In recent times, the use of the word школад chocolate in our speech has become a habit. The restaurant opened from a chocolate spot. That is, the word chocolate here means a convenient location of the restaurant, an address with a large number of clients. Or he uses the word школад chocolate to refer to a woman's stature, elegance, beauty.

Доля-(in the sense of share).

Поставка-Delivery (deliberate behavior).

Центр, централный банк, центральный телеграф-Center, central bank, central telegraph.

Давно-Long ago, for example, давним-давно (Russian word) аллақачон йўқ бўлиб кетган. It has been disappeared many years ago.

Прогресc-Progress (progress, in the sense of moving forward)-Прогресc бop. There is progress.

Условия-Condition, условияси йўқ-no condition, условия яратилмаган, no condition, no condition created.

Peгpecc-Regress. Регресс орқага кетаяпти. It is going backwards.

Контузия, контужен-Contusion, contusion (brain damage in the sense), that is, he went to Afghanistan and returned as a contusion.

Неполнценний Яъни у неполноценний одам-That is, he is an incomplete man.

Затарин-Мошинага юкни затарин (бостириб) қилиб босган, йўлда аварияга учрапти. In the sense of that: The man who hit the car with a load (stock up) and crashed on the way.

Yepecryp - too much (very, excessively, excessively) applies to the assessment of a person's stature, i.e., a large, stocky, small, unattractive, or greedy person. It is also used to assess whether the work being done is heavy or light.

Хромой-lame, “у храмой" he is lame. In this sentence, the letter " $o$ " after the letter " $p$ " is changed to " $a$ ".

Слепой-blind. "Нима у кур-слепой эканми? "Is he blind? You fall so much; can't you look me in the eye?"

Движение-(in the sense of action).

С лехкем паром-in the sense of "Be as light as a bird." In Uzbek, the letter " $e$ " after the letter " $k$ " is pronounced with the letter " $o$ ". Also, пешеход-pedestrian way, пешком- on foot, пропуска-permission, позор-shame, отдуши-from heart, sincerely, шустри, шустряк, шустрий-аgile, а так and so, пучше the best, вариант-variant, привет-hi, hello, слух-message, влияния-influence, принцип-principle, унификация-unification and etc. There are many other expressions that are actively used in modern Uzbek speech. 
There are also sectoral expressions that come from a foreign language through Russian language: For example, economic terms such as экспорт, импорт, уклад, платёж, платёжка- export, import, arrangement, payment.

Terms half Russian and half Uzbek such as кассация, кассацонний суд, инстанция суди, юқори инстанция, қуйи инстанция, гражданский бракcassation, cassation court, court of instance, higher instance, lower instance, civil marriage remain relevant today.

Передача (extension), пожар (fire), свет (lamp), редакция (editorial), автотpacca highway, шофёр driver, шопер driver, шофер driver, катастрофа саtastrophe, биосфера-biosphere, оппонент opponent/reviewer/, yже-already, конец-the end, кино фильм-movie, сериал-serial words common in everyday life. Телефильм-telefilm, телепередача-tele channel, дистанция-distance, перевод-translation, подлинник-оriginal, копия-сору, ксерокопия-Хегох, копейка-coin etc. The word копейка -coin is widely used to describe a person in a figurative sense. For example, "У одам копейкага қиммат”, “копейкага хам арзимайди". "копейка" that person is worth a penny, "not even a baby". This implies that the person in question has no reputation in the life of society and among the community, friends.

In Uzbek oral speech, many words are also formed through the phrase technique: техника, техник, технология. техникавий тараққиёт, технический перевод, техника-technique, technique, technology, technical development, technical translation, technical field.

In the Uzbek language, such Russian terms as медицина-medicine, больницаhospital, нарокоман (нашакаш), реанимация, реанимация хонаси, операция (жаррох), операционной хона, реакция-drug addict, resuscitation, resuscitation room, surgery, operating room, reaction, прививка, проба, анализ, гроб vaccination, probe, analysis, coffin are still actively used today.

Recently, the term "парниковий"-greenhouse is widely used in Uzbek speech. The term is mainly used for those who grew up in the house and means negative, that is, "incompetent", "cheap of parents", "masculine", "luxurious".

\section{Операционной проба.}

\section{Conclusion}

Such changes in the Russian language during the period of independence today also were put on the agenda to answer the question of how the language was in our history.

For example, the Khorezmian dialect, which has its roots in nine Oghuz, is historically close to the Turkic, Azeri, and Turkmen languages. Over time, internal and external factors have led to profound changes in the lexicon of these languages.

First, there were profound changes in verbal, verbal thinking.

Second, the Turkic languages were treated in the old Arabic script until the arrival of the Russians. Islam, as a religious value, unites their common interests, 
and language plays a decisive role in social space and time.

The growth of the social influence of the Russian language in the Turkic world has led not only to the isolation of the Turkic languages, but also to the differentiation (interdependence) of historically close languages.

Third, even today in Tashkent, the capital of Uzbekistan, 53\% of schools are taught in Russian. These efforts are also shaping the Uzbek language in the society.

Fourth, Russian is the official working language of the United Nations, along with English.

Fifth, the Cyrillic alphabet has a large written text that will continue to have an impact on the Uzbek audience for decades to come. Today, the Latin alphabet is used in kindergartens, primary and secondary schools, and higher education institutions, but meetings, events, state visits, and state and government office work of international significance are conducted mainly in Russian.

Sixth, although the Uzbek language law officially stipulates that only Uzbek, i.e. one language, is allowed in the country, two languages that are not written in the law are used. The official international office of the state and the language of the organization and interagency remain Russian. In this regard, it is safe to say that the principles of bilingualism are being followed in the state.

Seventh, in Russia, Uzbek migrant workers are the largest force in the world, forming a relationship and a carrier of ideas. Without denying the influence of spiritual values on the life of society, one should not turn a blind eye to the determination of economic and material factors in the development of spiritual maturity. The main factor that casts a shadow on the development of the Uzbek language is also related to its material side. The experience of developed economies also shows that language inevitably has a major impact on the language situation and policy. The language situation in Uzbekistan remains complex and serious.

\section{Conflicts of Interest}

The authors declare no conflicts of interest regarding the publication of this paper.

\section{References}

Brokaw, D. (2015). Letter from the USA/Aziz Djuraev in the Memory of Contemporaries (133 p.). Turon zamin ziyo Publishing House.

Djuraev, A. B. (2016). Current Problems of Uzbek Linguistics. Uzbek Oriental Studies: Today and Tomorrow “Collection of Scientific Articles” №7, Tashkent, 7-11.

Erkinov, A. (2015). Aziz Djuraev in the Memory of Contemporaries (pp. 150-151). Turon zamin ziyo Publishing House.

Karimov, N. (2020). Behbudi's Will. New Uzbekistan Newspaper, February 19, 2020, Issue 18.

Ulko, A. (2019). Is the Uzbek Language Only for Uzbeks? Why Is There Still a Problem with the State Language in the Country?

https://hook.report/2019/08/problema-uzb 